\title{
Good Leadership and Sustainable Governance: A Critical Assessment of Governance in Nigeria
}

\author{
Emmanuel A. OJEWUNMI \\ Department of Politics and International Relations \\ Lead City University, Ibadan. \\ Oyo State, Nigeria
}

\begin{abstract}
This research paper establishes that good leadership is a key condition to sustainable governance. This paper therefore, investigates the principles of good leadership and sustainable governance. With Causal and Descriptive Designs employed as the methodology, this work accesses how sustainable the democratic governance in Nigeria is. The words good and sustainable as related to governance cannot be absolutely divorced in the study of governance. The two key words in this discourse are so inextricably intertwined as though they are conterminous with each other. This is because the two key words focus on the same goal. To discuss one leaving the second out cannot bring desirable results for this discourse. For the governance of any given state to be sustainable, it must be a governance that is led and managed by good leadership and it should conform to the expected constitutional standard, that is legally constituted and that is being operated according to the rules and regulations of the country. It must be accountable to the people with the structure that allows a smooth hand over process. This paper therefore examines some of the definitions of good leadership, the conditions that can guarantee good governance and how they can be applied to the Nigerian situation in providing suitable governance that will not jeopardize the interests of the future generations.
\end{abstract}

The paper recommends that Nigeria needs a leadership that preserves the future. The Nigerian people need a leadership that not only protects the political, economic, social and environmental interests of the present but also protects the interests of the future generations.

Keywords:- Good Leadership, Sustainable Governance.

\section{INTRODUCTION}

This article considers various definitions of good leadership and sustainable governance and further establishes the synergies that exist between good leadership and sustainable governance. Good leadership, according to this research, is considered as a prerequisite for the attainment of sustainable governance in any given state.

Furthermore, the paper probes into Nigerian governance and investigates how sustainable the governance in Nigeria is. Those factors that can guarantee sustainability of governance in Nigeria are considered as myriad to the attainment of sustainable democratic governance and therefore the paper believes that as at the time of writing this paper, (July, 2020), the democratic governance in Nigeria is not sustainable.

Before conclusion, the paper gives some workable recommendations that can ensure continuous existence of governance in Nigeria.

\section{CONCEPTUAL FRAMEWORK}

There are two basic concepts in this research work that need our further discussion to enable the readers grasp the context in which they were used. The two key concepts are: good leadership and sustainable governance.

Good Leadership- From the onset, the concept of leadership has been given different connotations. To start with, different scholars have different perceptions about the concept of leadership. According to Benscotter and Rothwell (2012) leadership is defined "as a process of individual influence on a group of individuals aimed at the achievement of individual and or common goals of the group or the organization". Further to this, MacArthur quoted Anderson (2015) also sees leadership in form of a true leader that has confidence to stand alone, that has the courage to make tough decisions and that has compassion to listen to the needs of others. Such a leader does not target to become a leader but he becomes one as a result of his quality actions and integrity of his Intent (MacArthur in Anderson 2015). In another dimension, leadership can be defined as a dynamic relationship based on mutual influence and common purpose between leaders and collaborators in which both are moved to higher levels of motivation and moral development as the effect we intended change. Badawi (1999) furthermore perceives leadership as leaders inducing followers to act for setting goals that represent the values and his motivations, the wants and needs, the aspirations and expectations of both leaders and followers.

Based on the above premises, leadership can be seen in form of being ordinary people with extraordinary determination. Leaders that have actions that inspire others to dream more do more and become more. Leadership involves working most effectively accepting responsibility and giving the credit of achievement to the entire team. Leadership also involves setting out of goals with the view of achieving and even surpassing such rules. Leadership comes from a leader that possesses a clear vision college 
integrity honesty-humility and clear focus. Great leaders help people reach their goals, they are leaders that are not afraid to hire people that might be better than the them, and they take pride in the accomplishments of those they help along the way (Gleeson: 2016). According to Gleason (2016), the 10 unique qualities that make one to become a great leader are having: Faith in one's beliefs, making the hard choices, earning respect of the team, knowing the team, knowing that the people are the key to success, articulating a clear vision, pushing people to be their best; serving a greater cause; focusing on helping the team and finally, not leading by force.

Furthermore some of the good leadership qualities involve; being accountable to the people they lead; honesty in words and actions; demonstration of the spirit of humility; demonstration of love and affection to the people they lead demonstration of the fear of God in the execution of their policies both internally and externally; observance of the rule of law obedience to the constitution of the land; good initiative and judgmental qualities; incorruptibility and leading by good example; selfless services to the people; preparation to quit the office when ovation is loudest among others. In addition, good leadership possesses emotional intelligence; this involves selfawareness, self-management, social awareness and social skills. Good leadership also possesses good communication skills that involves being inspirational and persuasive. Finally, good leadership is a team builder that prepares ahead of the future leaderships.

\section{Sustainable Governance}

Generally, by mentioning the word governance, what comes to mind is the concept of government. Governance and government both have a common root word from the Greek language "kubernaein" which means "To steer" (Gianluca, 2007). The fact is that governance is more than just government. It is a complex yet universal force that exists in all societies. People use governance in their daily relationships such as corporation and countries. Governance deals with the management of interactions and activities among the citizenry.

According to World Bank, there are three distinct aspects of governance. The three aspects are; the form of political regime; the process by which authority is exercised in the management of a country's economic and social resources for development; and lastly, the capacity of governments to design, formulate and implement policies and discharge functions (Gianluca, 2007).

The concept of governance can be defined as the management of regime. Governance is basically concerned with how rules or structures affect political action and the prospect of solving given societal problems. (Hyden and Bratton, 1992) Likewise governance is more than just sustenance of the regime, but also means the capacity to stand the test of situations where regime changes are needed to meet new demands or deal with new problems and challenges of the society. Kayode and Soyode (undated) define governance in terms of measurement and evaluation of performance.

Governance in a nutshell means the method in which power is made use of in the management of the country's social and economic resources for development purposes. In addition, governance is conceptualized and focuses on such issues as 'legitimacy of government' open practices (degree of democratization) accountability of political and official elements of government, (Media Freedom, transparency of decision-making, accountability mechanisms) competence of government to formulate policies and deliver service respect for human rights and the rule of law (individual and group rights and security framework for economic and social activity, participation).

On the other hand, sustainable means, ability to be able to maintain a process at a certain rate or level. Besides it is the ability to continue over a period of time. It is a process that causes little or no damage to the political economic social and environmental matters of society and therefore able to continue for long time without any disruption.

Based on the above premises, sustainable governance means retention of strategy across the business and management of goal setting that entails a reporting process; straining relations with external stakeholders. and ensuring overall accountability. Furthermore, sustainable governance involves generating policy outcomes that maintain or improve the quality of life for present and future generations without placing an unfair burden on future generations. Finally, sustainable governance integrates the principle of systems thinking and appreciate the complexity of a decision-making environment.

For governance to be sustainable in any given state; the following factors need to be given room to operate. They are as follows:

Freedom of voting and free fair elections: Elections are central to the principle of representative democracy all over the world (Muse and Afolabi, 2016). A free and fair election is one in which the political system and processes guarantee that each voter will be allowed to vote only according to his conscience but in a conducive environment devoid of threats, fear and violence, corrupt practices, impersonation and intimidation in any form or kind (Muse and Afolabi, 2016). In other words, a free and fair election is one in which electoral laws are strictly adhered to by all stakeholders (All africa: 2011).

Sustainable governance also involves participation of both men and women who have acceptable age by the constitution. Participation needs to be informed and organized. This means freedom of association and expression on the one hand and an organized civil Society on the other hand (Okuouye, 2012: 407). It also allows the enforcement of the rule of law. All members of the state irrespective of age, sex, financial status, educational qualifications, and so on are treated equally before the law. The same law applies to all people. 
Sustainable governance also allows transparency. Those in the leadership of the state carry out their official responsibilities in a manner that follows rules and regulations. The general public is given the opportunity to freely access the actions of those in governments without threat. Furthermore, accountability is another key factor that ensure sustainable governance but it must be noted that accountability cannot be enforced without transparency and the rule of law. (Okunoye, 2012). Likewise, effectiveness and Efficiency on the part of those in governance is a key to its sustainability.

From this premise, governance can mean exercise of political, administrative and economic power to manage the affairs of any nation at all governmental levels. Similarly, governance is concerned with how rules or structures affect political actions and the prospect of solving given societal problems. The study of governance involves the identification of the conditions that facilitate good governance and by implication, effective problem solving (Gordon, H \& Bratton, (1992). So, to distinguish responsible from irresponsible governance, depends on political leadership's attitudes towards their roles as public trustees of the state. In other words, it covers their orientation towards the sanctity of the civic public realms; sharing information with citizens, and their adherence to the rule of law. In his argument, Bello Imam, explains that governance should be understood as the mechanisms whereby an institution or organization (be it family, the nation-state or elements of it) incorporates the participation of relevant interest groups in defining the scope and content of its work including the capacity to mediate among those interests when they enter into conflict and the means whereby it demonstrates the accountability of those who support it through its mission mandate and the application of its resources in pursuit of its goals (Bello-Iman: 1997). In addition, the nature of any governance, good or bad is to be determined at the more general and the higher level, by the essential characteristics of the government that is in place, whether it is democratic, authoritarian or totalitarian. The freedom to associate or organize, and the freedom of the press may also be severely limited, particularly at the higher or central levels of the social order. This will in turn affect relations of governance, as the rights and abilities of people to have a say in matters of government will be limited (Bello-Iman, 1997). Furthermore, Adamolekun, (2011) sees governance as the exercise of political power to manage a nation. According to him, many observers have attributed the problem of persistent, underdevelopment in Sub-Saharan Africa (SSA) as due in large part to the poor governance environment (Adamolekun, 2011). A 1989 World Bank study of SSA also attributed this problem of underdevelopment to crisis of governance. This means the countervailing power has been lacking, the state officials in many countries of this region are serving their personal interests at the expense of the majority without being accountable. In SSA, politics has become personalized and patronage becomes essential to maintain power. Authorities in this region especially in Nigeria of today have assumed broad discretionary authority and lost their legitimacy. In Nigeria for example, information is being strongly controlled and voluntary associations are being co-opted or disbanded if found to be against the authority of the state. In the present dispensation of Nigeria, there is no freedom of expression, association, rule of law, electoral legitimacy, accountability, transparency and development-oriented leadership. This can be justified through detention of Omoyele Sowore in 2019, (presidential candidate of AAP in 2019 general election in Nigeria), and government closure of the venue to hold seminar at Ikeja, Lagos to discuss the continued detention of Sowore by the Directorate State Security (DSS). Meanwhile, while the court ruled and ordered for Sowore's release, the Nigeria Federal Government through DSS refused to comply with the court instruction and kept him in the custody of the Directorate of State Security (DSS) for many days until the intervention of the International comity (Ogundipe, 2020).

\section{$>$ The Attributes of Good Governance}

Before categorizing governance of any state as good or bad, sustainable or unsustainable, there are eight major characteristics that must be considered. Good governance that is sustainable is expected to have the following characteristics: Good governance must be participatory, consensus-oriented, accountable, transparent responsive, effective and efficient, equitable and inclusive, and the rule of law. In addition, such governance is to ensure that corruption is in check or minimized to a minimal level, views of the minorities are taken into account and the voices of minorities and vulnerable people are heard and considered during decision making. OCED e-books, (2001) argues that good governance is also responsive to provide for the present and future societal needs. Furthermore, good governance promotes equity and equality of treatment to all, and governance that is based on the concept of nondiscrimination. The basic consideration in good governance is being able to develop the resources and methods of governance (UNDESA, 2000). Moreover, in the context of social development parameters, it promotes genderbalance, enables synthesis of diverse perspectives and mobilizes resources for social purposes. Good governance in a nutshell, strengthens indigenous mechanisms and ensures efficient and effective use of resources. All civilized societies are expected to be based on the rule of law which is an essential component of good governance and that should engender and command respect and trust (UNDESA, 2000).

Summarily, according to the general principle of international organizations, good governance is found in a governmental leadership where the authority of the government is based on the will of the people and is responsive to them. It is when open democratic institutions allow full participation in political affairs and human rights protection that guarantees the right to speak, assemble and dissent, and it is when government and governmental institutions are pro-poor and promote the human development of all citizens that it can be said that such governance is good and sustainable. In short, it distinguishes between the institutions and process of governance and their content and quality (World Global Forum, 2002). 


\section{How Sustainable is Governance in Nigeria?}

The attributes discussed above as the factors that can ensure good governance are the necessary ingredients that can make any governance sustainable. To make governance sustainable in Nigeria, governance is expected to be kept strong, to keep going without destruction. It must be strengthened; it must have the ability to be produced or kept alive for an indefinite period without damaging the environment or without losing the quality of its resources. It must be reviewed from time to time in order to accommodate positive changes that are people friendly, pro-poor, and are beneficial to the general populace of the citizenry.

Based on these aforementioned, for Nigeria's governance to be sustainable, it must possess the quality of strength. It must be lively for an indefinite period. It must guarantee the security of lives and properties and constantly retain the quality of its resources. It must be widely acceptable to the majority of the populace. In addition, the factors that can further guarantee the sustainability of governance in Nigeria is that it must be accountable to the people. It must be transparent and open. Also, it must allow equality of religious groups, rule of law, and opposition must be allowed to express their views on all governmental policies without threat or cohesion. In addition, governmental policies must be widely acceptable, free of molestation from government's security organizations, encourages participation of citizens, responsive, effective, efficient and equitable development of all regions without favoritism. In the critical assessment of governance in Nigeria, all these factors are now becoming a myriad of problems to achieve.

To begin with, Fatokun argues that the interplay of religion and politics especially in Northern Nigeria since the emergence of the nation of Nigeria as a political entity, has put Christians at a greater disadvantage in employment, promotions and appointments and even in the matter of freedom of worship (Fatokun, 2012). To buttress his point of inequality of citizenry in Nigeria is the call made by a former Chief of Defense during General Olusegun Obasanjo's military regime (1976-199). Lt. Gen Theophilus Danjuma whom recently advised Taraba state indigenes and all northerners in general who were being killed to begin to carry arms so as to defend their lives and properties when the Federal Government through the Nigerian Armed Forces were unable to provide adequate security cover for them. Mkom said Danjuma gave this warning at the maiden Convocation ceremony of Taraba University, Jalingo Taraba state capital. Further to this, he says "He said the unnecessary killings which is a target to ethnic cleansing on the people of Taraba and Nigeria at large must stop, just as he called on the people to rise and defend themselves against the killers." The reporter further quoted Danjuma to have said as follows: "The etnic cleasing must stop in Taraba, and it must stop in Nigeria. These killers have been protected by the military, they cover them and you must be watchful to guide and protect yourselves because you have no any other place to go. The ethnic cleansing must stop now otherwise Somalia will be a child play. I ask all of you to be on your alert and defend your country, defend your state" he said. (Mkom, The Vanguard, March 24,2018). In support of Danjuma's recommendation, Bona in Today ng, (April 18, 2018) also reported Senator Gemade comment to support ethnic cleansing and to carry weapons to defend themselves from the frequent attacks of the Fulani herdsmen and Islamic extremists in the northern part of Nigeria on defendless local communities' dwellers which has turn all Christians in this region to second class citizens. In addition to this while speaking on the floor of Nigeria National Assembly as a Senator, Gemade says "This country is becoming a state without control. It is a state in which we have seen ethnic cleansing. It is a shame that a sitting government could watch criminality go to the level that we have seen it today. Rather than rise up and take very decisive steps against it, we embark on denials and shield this evil by just explaining with flimsy excuses, that these are communal clashes between communities" (Today ng, April 18, 2018).

The leadership style of Nigeria leaders is giving a wrong signal to the people they govern. It is in today's Nigeria that you see leaders who are supposed to render selfless services to the entire citizenry displaying recklessness spending, tyranny and all sorts of wickedness. Yusuf, (2012) argues that the judges and other legal luminaries who are supposed to put them (that is, government) in check, throw their responsibilities to the dustbin, because they also lack consciousness of their obligations to God having being swayed by pressure groups, self-interest or by their own prejudice and preference, to deviate from justice (Yusuf, 2012). Government officials in Nigeria are not ready to render self-less services but to act as bosses and military commanders. Instead, of the elected people's representatives to see themselves as servants and representatives of their people, they act contrary to these. They feel they are not accountable to the people. The wickedness and ruthlessness of the Nigerian politicians has made many fearing people in Nigeria to detest the muddy terrain of present day Nigerian politics. Such people have decided not to be part of Nigerian political activities and this has greatly affected the quality of governance in Nigeria. The deficiencies in the governance of Nigeria have greatly affected the civil servants. Most of them are no more punctual to office or dedicated to their duty. A few of them who occupy high echelon offices take bribes and engage in corruption and embezzlement of public funds.

To buttress this point, is the case of the suspension of Nigeria's Economic and Financial Crimes Commission acting chairman, Ibrahim Magu from office because of his fraudulent diversion of recovered funds and seized assets which ran into billions of Naira (Adesokan, 2020). Likewise, in December, 2010 the Police Service Community found Magu guilty of action prejudicial to state security; withholding of EFCC files, sabotage, unauthorized removal of files, and acts unbecoming of a police officer and awarded him several reprimands as punishment. In addition, Magu was also accused of forcing the Federal Capital Development to award a contract to 
Africa Energy, a company owned by the same person, who furnished his residence (Adeshakin, 2020). In addition to these, the country's Niger Delta Development Commission has also been engulfed in a high level of financial misappropriation as reported by Ebiri (2020) in his report titled "Outrage over Fraud, rot in NDDC, Niger Delta, According to Ebiri, "20 years of NDDC's existence has been characterized by inefficiency, misappropriation, mismanagement, sorrow, continuous suffering of the people, polluted environment, poor state of infrastructure and award of contracts that only existed on paper, with monies disbursed, recent happenings in NDDC are not only disgraceful but also tragicomedies and deliberate plans by the enemies of the area to ensure no development agency works".

In addition, according to a scholar of Religious ethics, Ayantayo, (2012) "one can hardly get anything from the government secretariats without greasing the palms of those in charge of what one wants". Some of them especially women engage in "pp" private (business) practice such as selling of wares and domestic needs both within and outside their offices. A few men have their shops or business outlets to which they sometimes divert government things like stationery and motor parts among others". The major factors that turn the civil servant to less productive and inefficient in Nigeria are identified in the pattern of governance in Nigeria. The factors among others are poor pay, delayed salary payment, poor housing, poor working conditions, poor transportation problems, prevalence of get-rich quick syndrome among Nigerians, lack of motivation, poverty, lack of supervision and poor enforcement of work ethics and the group norms and cultural values of the society and religious statement (Batshore, 1998). With all these aforementioned, there can never be a cordial working relationship between the civil servants and the government in Nigeria. For example, it took over a year before Federal Government of Nigeria and Labour Union were able to agree on the thirty-thousandnaira minimum wage in 2019. All these are avenues for poor services from the civil servants. Meanwhile, effectiveness and efficiency in the act of governance mean that processes and institutions produce results that meet the needs of society while making the best use of resources at their disposal. This also involves the sustainable use of natural resources and the protection of the nation's environment. The poorly treated and motivated civil service cannot take positive lead in effective and efficient service provision, which definitely leads to good and sustainable governance. Nigeria's civil service can by no means ensure effective service delivery theoretically and practically because of its bad and wrong orientation to perform official assignments "A ki se ise Oba laagun" (one must not use his/her full energy for government work).

In addition to this, the high level of corruption, nontransparency and funds misappropriation among the elected and political class, the stealing syndrome has also engulfed the working class of Nigeria. Many of the civil societies are after what they can take out of government resources and not what they can offer to the country. All these are dangerous signals to sustainable governance in Nigeria. In fact, good governance that will consequently translate into human and material development in Nigerian situation requires sincere commitment of the governing and working classes to the contents of the oath of their office.

\section{RECOMMENDATIONS}

Based on the above problems identified in governance in Nigeria, this paper will like to recommend the following:

The leaders of worker's unions as it was in the traditional Yoruba society in Nigeria on their own should enforce code of ethics regarding their work by ensuring that their members in their different places of work adhere strictly to work ethics (Ayantayo, 2001) in order to guarantee an efficient and effective civil service for the country. Inaddition, the government should give more attention to the payments of worker's gratuity and pensions to retirees and prompt payment of monthly salaries to current workers. Until Nigeria as a nation develops a functioning reward and punishment mechanism structure in public offices, swearing an oath would remain a mirage.

Meanwhile to ensure sustainable governance, the primal credential for the government officials is good education, such as would enable the leadership to combine "ideas and power, intellectualism and politics" (Nwabueze, 2018). Good quality leadership is a critical part of Nigeria's problem of governance because the educational qualification prescribed by our political leaders by section 131(d) as amended by the National assembly in 2010, and section 318(1) of the constitution does not equip them to be able to combine "ideas and power, intellectualism and politics" (Nwabueze, 2018). There is no way to guarantee a good and sustainable governance in a country where a semi-literate President or Governor is entrusted with the pinnacle of the leadership. The little literacy and academic exposure that is acquired from the educational system at the primary school level will soon be lost due to the lack of a reading culture that pervades the Nigeria society, caused to a considerable extent by the enthronement of wealth as the determinant of social standing and the consequent inordinate pursuit of it and other mundane, non-intellectual pursuits (Nwabueze, 2018). The low educational qualification required for elective political leaders (in Nigeria) has resulted, sadly, in the relegation of intellectualism in government and politics in the Country. The fact of the matter is that intellectualism is concerned essentially with the notion of "ideas", this means ability to adequately hold ideas and to reason them out as expected of a visionary leader. An intellectual leader must be a person that is involved in creative and rational thinking about the world around him, about humanity, human relationship and the governance of human society. He is a person that is dedicated to the study and understanding of ideas that govern and shape our world, society, the organism known as the "state" and generally to the intellectual pursuits and interests (Nwabueze, 2018). 
In addition, anyone aspiring to govern and lead the Nigerian state as President, Governor, Senator, Minister etc. is expected to be an energetic person with a high level of energy and strength that will help him to engage in the arduous task of mobilizing the people for national transformation. Mobilization of the people for such a purpose being is one of the most arduous tasks of political leadership. The wear and tear and stress of life, coupled with the health and other challenges, rob everyone who is above the age of 70 years, of the energy required for the job of governing Nigeria effectively and efficiently. For governance in Nigeria to be sustainable, Nwabueze (2018) believes that there is a need of leadership that is not only committed to democracy and constitutionalism, but also one that is dedicated, single-minded, selfless, disciplined, patriotic and highly motivated in the national interest with a deep concern for the public good/welfare, a leadership that will be able to mobilize the various strata of society and that will be fully equipped to sacrifice its vested economic interest in the preservation of the status quo (Nwabueze, 2018).

Therefore, for any governance to be sustainable, it must be a government that preserves the future. Nigeria's government and political leadership needs to govern in such a manner that they not only protect the political, economic, social and environmental interests of the present, but also protect the political, economic, social and environmental interests of the future generations. In addition, not only cognizance of present economic, political, social and environmental needs should the governments keep in mind and protect, but also be mindful of such needs for the future generations.

In Nigeria for example, the country keeps on collecting loans and advances here and there from different international financial organizations, by so doing, the government is creating problems for the future generations. Generally, governments at all levels and the Nigerians are not living sustainably. The economic principles of the country do not indicate that our governance is sustainable. They destroy the environment and consume resources anyhow without keeping the interest of their future generations in mind. The case of the South-South of Nigeria is a good example. The environmental pollution of a high magnitude has affected many natural resources that the future generations could fall on during their time. And all those who speak against the government are being seriously dealt with. This can remind us of the case of the human rights activist, Ken Saro Wiwa who was executed by hanging during the reign of a former military dictator General Sani Abacha, (the maximum ruler) for asking for his people's fundamental human rights. The unfortunate thing about this is that the trend has not been reversed as at 2020, the time of writing this paper. Till now, we keep on destroying our environment. In a like manner, the rate at which forests are being destroyed without replacement in the western part of the country creates fear for the supply of timber for the future generations in Nigeria.
Further to this, another dimension to consider in this subtopic is on the labour unions demand for salary increment. The pertinent question to ask ourselves is that: "Is it sustainable to ask for salary increase any time there is inflation in the country?" Is labour union creating sustainable governance or creating problems for the future of this nation? As at today, the pay home cannot take us home, why? This is because the pay home of any average worker cannot match the rate of inflation that exists in Nigeria nation, and as the government keeps on increasing worker's salaries the more the rate of inflation keeps on skyrocketing at the expense of the average Nigerians. Likewise, do the Nigerian governments at all levels have any concrete plan for the millions of the idle youths and graduates that are being produced every year in the country? Can the situation adequately guarantee the future of this nation? In reality, all these indicators are showing a crisis for the future.

Similarly, the relationship between the three arms of government at the federal level, doesn't guarantee a sustainable governance. In a situation where the judiciary is not free of frequent incursion of the executive, cannot assure us of the sustainable governance. For example, the judge who ruled that the detained 2019 presidential candidate of one of the political parties in Nigeria should be released on bail was later reported to the Nigerian Judicial Commission (NUC) for sanction because he ruled against a governmental agency is an indicator for unsustainable governance in Nigeria (Yahaya; 2019). Also, the executive intervention in the legislative leadership selections process is against the rule of law, as this has turned the legislative arms to become puppets of the executive arm of government.

Also, the salary structures and allowances of the political class in Nigeria have been considered to be too high and their continuous sustainability cannot be guaranteed for long without future financial crises. The parliamentarians' pattern of life and flamboyant financial behaviour are some of the factors that are drawing many youths to crime. They live as if they are a special breed of Nigerian people.

Finally, the social life in Nigeria has gone bankrupt. The impact of the Faith-Based organizations is not felt as expected. Despite the frequent increase in the places of worship in Nigeria, (Nigeria is popularly regarded to have the highest numbers of religious centres and the most religious nation in the world) yet the rate of moral decadence continues to grow rapidly. To illustrate this factor, in the first tenure of civilian administration of President Muhammadu Buhari in Nigeria (2015-2019), the rate of suicide has greatly increased, the rate at which people are being laid off from their places of employment has increased, exodus of Nigerians to other countries through illegal means show the extent of the suffering of Nigerians. Further to this, is the rate at which the young ladies are being enrolled into prostitution is an eyesore, drug abuse, and internet fraud popularly known as "yahooyahoo" have now permeated the land of Nigeria. Incessant 
killing especially in the southeast/south-south and northern regions are evidences that the future/continuous existence of Nigeria is at risk. The rate at which people are being kidnapped especially in Kogi, Plateau, Benue, Kano and Kaduna states in Nigeria has skyrocketed. Similarly, the rate at which the gunmen are killing innocent people in places like eastern parts, Zamfara and Katsina states has gone beyond imagination. The continuous invasion of the Boko Haram insurgents in the northeast of Nigeria especially in Borno, Yobde and Adamawa states is a threat to the sustainable governance in Nigeria. The crime rate in Nigeria is increasing daily without being abated. Some leaders of the Faith-Based organizations are also not showing good examples. They are frequently being caught up in the web of fraud, killing, corruption, immorality of different kinds which encouraging the youths to follow their steps. All the aforementioned are indicating that the interests of the future generations in Nigeria are not sustainable.

Based on these factors, in order to reverse the trend, Nigeria needs a leadership that has no moral decadence, a leadership that is transparent, focus, devoid of tribalism and favouritism, the leadership that is not parochial in views and opinions, a leadership that has been tested and trusted and that can stand the test of time. A leadership that is seen to practice what it preaches. Nigeria needs a leadership that has the interest of the future generations in mind, that is tolerant, honest, public spirited, fair-minded, law-abiding, devoted, disciplined, creative and non-extravagant etc. A leadership that is not sentimental and narrow minded. All these are qualities of a leadership that can sustain governance in Nigeria.

\section{CONCLUSION}

The paper has observed that the nature of the present leadership in Nigeria can never guarantee a good and sustainable governance because it does not have the required skills and background that are in line with that purpose. What the country of Nigeria needs is technically competent and visionary political leaders. Leaders that are devoid of sentiment, religious bigotry and extremism. A leadership that is proactive, selfless, and capable of thinking ahead of time, a leadership that has the right mentality and attitude and avoids procrastination and that it is also agile, and up and doing, that will be prompt in decision making, that will be devoid of political "godfatherism" and self centredness.

It is only when Nigeria possesses this kind of leadership that the citizenry of Nigeria can boldly be assured of a good and sustainable governance. As at now, the nation of Nigeria is seriously bleeding to death, and urgently in need of a leader to save it (Nwabueze, 2018) from the approaching political, economic and social upheaval. Finally, Nigeria needs a kind of leadership that have a large heart; that accommodate and welcome all shades of opinions, either positive or negative. The leadership that guarantee equitable distribution of resources, the resources of the country that should not be monopolized by a few privileged citizens (Nwabueze, 2018). There is the need of a leadership that can ensure adequate security of lives and properties. It is on these that Nigerians can have an assurance of a sustainable governance.

\section{REFERENCES}

[1]. Adamolekun, L (ed) (2011): “Governance Context and Reorientation of Government in Public Administration in Africa: Main issues and Selected Country Studies": Second edition. Ibadan. Evan Brothers: p3

[2]. Adeshokan, O. “Nigeria's EFCC Boss Suspended from Office Following Secret Tribunal". Accessed from https://www.theafricareport.com on July 25, 2020.

[3]. Allafrica (2011). Nigeria: How to Sustain Free and Fair Elections. Accessed from allafrica.com/stories/20110030059.html on July 25, 2020.

[4]. Anderson, A.R. (2015): Good leaders Are Invaluable to A Company; Bad Leaders Will Destroy it. Accessed from: www.forbes.com/sites/amyanderson/2013/01/14/g ood-leaders-are-invaluable-to-a-company-badleaders-will-destory-it. (July 20, 2020)

[5]. Ayantayo J.k (2001) "The Yoruba Traditional Economy in Ethical Perspective”. Forthcoming in Nigerian Journal of Economic History, Series 3, 2001.

[6]. Ayantayo, J.K. "Renewal of Work Ethics as SineQua-Non to Promotion of Good Governance" in Ayantayo et al. p56

[7]. Badawi, J. (1999). Leadership: An Islamic Perspective. United States of America (USA). Islamic Shurah Council of Southern California.

[8]. Batshore, E (1998) "The reform of work place Industrial relation. Theory Myths and Evidence”. Oxford: Claredon press, p.86

[9]. Bello-Iman I.B (Ed) (1997); "Governance in Nigeria: Economy Politics and Society in the adjustment Years 1985-1995." Ibadan. SterlingHarden Publishers. p2

[10]. Benscotter, George \& Rotwell, William. The encyclopedia of Human Resourse Management. Accessed from: https://iiste.org on July 25, 2020.

[11]. Bona, S, Today.ng April, 182018.

[12]. Citizens, Business and Governments.2002. Dialogue and Partnerships for Development and Democracy. Marrakesh. Morocco 18-13 New York. www.unpan.orgwww.globalforom.ma

[13]. Fatokun S.A (2012) "Christianity and Good Governance in Nigeria" in Ayantayo J.K, Dada O.A and Lebaodan H.A.2012. "Religion and Governance in Nigeria”. Department of Religious Studies U.I. Samprints \& Graphic Co. p. 23

[14]. Gianluca, C (2007) "e-governance in Africa from Theory to Action: a hand book on ICTS for local governance". Trenton, New Jersey. Africa World Press. 
[15]. Gleeson, B. 10 Unique Perspectives on What Makes a Great Leader. Accessed from https://www.forbes.com on July 25, 2020.

[16]. Gordon, $\mathrm{H}$ \& Bratton, M. (Ed) (1992) "Governance and Politics in Africa". Boulder and Longdon, Lynne Reiner Publishers.

[17]. Hyden, G \& Bratton, M. (ed) 1992. Governance and Politics in Africa. Boulder and London. Lynne Reinner Publishers.

[18]. IISD: The Essence of Leadership for Achieving the Sustainable Development Goals. Accessed from Https://sdg.iisd.org on July 25, 2020.

[19]. Kayode, F. Oyejide, A \& Soyode, A. Governance and Polity in Nigeria: Some Leading Issues: Ibadan University Press.

[20]. Mkom, J. The Vanguard, March 24 $4^{\text {th }}, 2018$.

[21]. Muse, S.A. \& Afolabi, A.B. "Religion, Leadership and Democratic Sustenance in Nigeria: assessments and Recommendation", in Ishola, H.T.K. \& others, (ed):2016 "Religion Education and Leadership". National Association for the Study of Religions and Education (NASRED). Oyo, Omo-Oje. p 30.

[22]. Nwabueze, B: (2018) "Crisis of Governance in Nigeria”. Ibadan. John Archers. P 63.

[23]. OCED e-books entitled citizens as Partnersinformation, Consultations and Public Participation in Policy-Making (2001).

[24]. Ogundipe, S. Again SSS Refuses to release Sowore Despite Pleading to Obey Court Order in Premium Times. Accessed from www.premiumtimesng.com of July 30, 2020.

[25]. Okunoye, J. O. (2012). The Role of the Church Towards Achieving Good Governance in Nigeria in Ayantayo, J. K, Dada O.A \& Lebaodun, H. A. Religion and Governance in Nigeria. Ibadan, Samprints and Graphics.

[26]. UNDESA, Economic Governance: Guidelines for Effective Financial Management New York. 2000.

[27]. Yahaya, H. Sowore: Why SSS Cannot Report Justice Taiwo to NJC-Falana. In Premium Times. Accessed from https://www.premiumtimesng.com on July 30, 2020.

[28]. Yusuf; M.G. "Politics and Governance in Nigeria; The Relevance of Islamic Principles" of Shura and Mas'uliyyah in Ayantayo et al Ibid p 43. 